\title{
COMPARATIVE STUDY BETWEEN OXYTOCIN VERSUS TRANEXAMIC ACID AND ETHAMSYLATE COMBINATION IN REDUCING INTRAOPERATIVE BLOOD LOSS IN MYOMECTOMY
}

\author{
By \\ Ammar M. Al-Morsi, Kamel N. Abdul-Galeel and El-Sayed A. El- \\ Desouky
}

Department of Obstetrics and Gynecology, Faculty of Medicine, Al-Azhar University

Corresponding author: Ammar M. Al-Morsi, Mobile: 01555468790

\begin{abstract}
Background: Fibroids are the most common benign pelvic tumors affecting about $20 \%$ of women above 35 years of age. The diverse symptomatology of fibroids can be attributed to size, number and location of the tumors. The common symptoms include menorrhagia, infertility, abdominal mass and pressure effects.

Objective: To compare the efficacy of tranexamic acid and ethamsylate versus IV oxytocin infusion in reducing blood loss during abdominal myomectomy.

Patients and Methods: This study involved ninety women undergoing abdominal myomectomy for symptomatic uterine myoma divided randomly into three equal groups: Group A (Tranexamic acid and ethamsylate group) received $1 \mathrm{~g}$ tranexamic acid (2 ampoules of kapron $500 \mathrm{mg}$ ) and $(1$ ampoule of dicynone) IV just before skin incision, Group B (Oxytocin group) received $30 \mathrm{IU}$ of oxytocin in $500 \mathrm{ml}$ normal saline will be administered during myomectomy, and Group C (Saline group) received $110 \mathrm{ml}$ normal saline IV just before skin incision. This study was conducted in Sayed Galal Al-Azhar University Hospital and El-Galaa Teaching Hospital during period time from December 2018 to December 2019.
\end{abstract}

Results: Using $1 \mathrm{~g}$ tranexamic acid and 1 ampoule of dicynone in abdominal myomectomy resulted in a significant reduction of blood loss than using $30 \mathrm{IU}$ oxytocin in $500 \mathrm{ml}$ normal saline immediately before the start of the surgery $(509.24 \pm 57.28 \mathrm{ml}$ in Tranexamic acid and ethamsylate group vs. $720.13 \pm 112.62 \mathrm{ml}$ in oxytocin group).

Conclusion: Tranexamic acid and ethamsylate are more effective in reducing the transfusion requirement than oxytocin with more stable hematological and hemodynamic profile.

Key words: Tranexamic acid, ethamsylate, oxytocin, blood loss, abdominal myomectomy.

\section{INTRODUCTION}

Uterine myoma is the most common benign tumor in women. Various prevalence rates ranging from $20 \%-40 \%$ are noted in different literatures. The incidence as per the histological diagnosis is much more than the clinical diagnosis. Approximately $60 \%$ of women above 45 years of age are harboring myoma (Reis et al., 2016). Myoma is mostly asymptomatic. Size and location are the main factors that determine if a myoma leads to symptoms and problems. Important symptoms include abnormal uterine bleeding, abdominal discomfort, bloating, painful defecation, backache, 
urinary frequency or retention and infertility. It is associated with impairment of health related quality of life (Bano et al., 2017).

There are several strategies for the treatment of fibroids, but myomectomy remains the most common and the most efficient uterus-sparing treatment (Cohen et al., 2016).

Myomectomy is an invasive surgical procedure and can be done abdominally, laparoscopically or by robotic method. (Farag et al., 2018). Substantial intraoperative blood loss and the requirements for blood transfusion remain major consideration for abdominal myomectomy (Petermans et al., 2016).

Cochrane Library review discussed several pharmacologic agents to reduce blood loss during myomectomy (Saha et al., 2016). One of the used agents is tranexamic acid. Tranexamic acid is not a uterotonic agent; TA is an anti-fibrinolytic agent better known to gynecologists for oral use as a treatment of menorrhagia, and to trauma surgeons where it has been shown to reduce blood loss (Lecker et al., 2016).

Several randomized clinical trials have been published which have evaluated and reviewed the efficacy of tranexamic acid in the management of abnormal gynecological hemorragic conditions. It is not certain how efficient tranexamic acid is in treating women with normal reproductive function and diagnosed with abnormal bleeding caused by uterine fibroids (Bradley and Gueye, 2016).

Ethamsylate is a hemostatic agent. It has been shown to reduce bleeding time and blood loss from wounds (Fatah et al.,
2018). Etamsylate limits capillary bleeding through its action on hyaluronic acid and initial studies showed a reduction in intraventricular haemorrhage. Etamsylate may also have an effect on the microcirculation, encouraging platelet aggregation and vasoconstriction and therefore haemostasis. It also inhibits the effects of the prostaglandin mediated vasodilatation and increased capillary permeability, thereby reducing oedema secondary to capillary leakage (RamosSánchez et al., 2018).

Oxytocin is a utero-tonic drug it is the first choice drug for enhancing uterine contraction after delivery (Vallera et al., 2017). Oxytocin is benefecial in reduction of intra operative blood loss at cesarean section and reduces rates of postpartum hemorrhage (Kuzume et al., 2017).

Data from a meta-analysis of two randomized trials including 80 women showed that the infusion of oxytocin intraoperatively may be a safe and reliable method to help decrease blood loss during abdominal myomectomy compared with physiologic serum (Atashkhoei et al., 2017).

The aim of the current study was to compare between the effect of Tranexamic acid and Ethamsylate versus Oxytocin compared to placebo regarding their efficacy to decrease blood loss in transabdominal myomectomy.

\section{PATIENTS AND METHODS}

This prospective randomized controlled trial was conducted at Sayed Galal, Al-Azhar University Hospital and El-Galaa Teaching Hospital during the period time from December 2018 to December 2019. The study included a 
sample of 90 women requiring abdominal myomectomy. All patients seeking treatment for symptomatic leiomyomas was invited to participate in the study.

Patients were divided into three equal groups: Group 1 received $1 \mathrm{~g}$ tranexamic acid (2 ampoules of kapron $500 \mathrm{mg}$ ) and (1 ampoule of dicynone) IV just before skin incision, Group 2 received $30 \mathrm{IU}$ of oxytocin in $500 \mathrm{ml}$ normal saline administered during myomectomy, and Group 3 received 110 $\mathrm{ml}$ normal saline IV just before skin incision.

The study included premenopausal patients aged between 30 to 50 years old, five or less symptomatic uterine myomas, maximum diameter of the largest myoma was $6 \mathrm{~cm}$, all myomas were subserous or intramural and uterine size less than 24 weeks pregnancy.

Patients with history of previous surgery, hypertension, cardiac and pulmonary diseases, patients who have bleeding disorders, anemia $(\mathrm{Hb}<10 \mathrm{~g} \%)$, chronic endocrine or metabolic diseases such as diabetes, obesity (body mass index $>30 \mathrm{~kg} / \mathrm{m}^{2}$ ) and cases that required intraoperative conversion of myomectomy to hysterectomy were excluded from the study.

All included women were subjected to the following: Preoperative: History taking including personal, present, past and obstetrics and gynecological history. Physical examination including: General examination, assessment of vital data, assessment of general condition, abdominal and pelvic examination, assessment of the uterine size and assessment of the size and location of the largest myoma if it is palpable. Laboratory
Investigations: Complete blood count. Ultrasound was performed to assess the number and location of myomas and largest myoma diameter.

Intraoperative: In all operations, the abdomen was exposed through a Pfannenstiel incision or midline vertical incision. Blood loss was estimated by measuring the amount of blood accumulated in the suction container minus used irrigation solution plus the amount of absorbed blood in used sponges. Blood lost in surgical sponges was calculated by the following formula: \{postoperative wet sponge weight (g) minus preoperative dry sponge weight $(\mathrm{g})\}$.

Postoperative: Follow up was every hour during the first 6 hours, and then at 12, 24 and 48 hours, and every additional 24 hours thereafter until discharge. Complete blood count was 24 hours after surgery.

The primary outcome of this study was to compare the intraoperative blood loss in the three groups. Other secondary outcomes were also compared including: the need for intraoperative blood transfusion, operative time in minutes, Difference between pre and post-operative hemoglobin and hematocrit levels and duration of hospital stay in days.

\section{Statistical Methods:}

Data were analyzed using Statistical Program for the Social Science (SPSS) version 20.0. Shapiro-Wilks test and histograms were used to cheked the normality of data and all our variables were normally distributed. Quantitative data were expressed as mean \pm standard deviation (SD) and range. Qualitative data 
were expressed as frequency and percentage.

The following tests were done: A oneway analysis of variance (ANOVA) when comparing between more than two means. Post Hoc test: Least Significant Difference (LSD) was used for multiple comparisons between different variables. Chi-square (X2) test of significance was used in order to compare proportions between two qualitative parameters. Pearson's correlation coefficient (r) test was used for correlating data. The confidence interval was set to $95 \%$ and the margin of error accepted was set to $5 \%$. So, the p-value was considered significant when $\mathrm{P}$-value $<0.05$.

\section{RESULTS}

There was no significant difference between the three groups with respect to their age, weight, height, body mass index (BMI), parity, myoma number, myoma stage, size of the largest myoma, uterine size, initial hemoglobin and history of the previous scar. No statistically significant difference between groups according demographic data (Table 1).

Table (1): Comparison between group $A$ and group $B$ and group $C$ according to demographic characteristics

\begin{tabular}{|c|c|c|c|c|}
\hline $\begin{array}{ll}\text { Garameters } & \text { Groups } \\
\end{array}$ & $\begin{array}{c}\text { TXA+ Ethamsylate } \\
(n=30)\end{array}$ & $\begin{array}{c}\text { Oxytocin } \\
(\mathbf{n}=30)\end{array}$ & $\begin{array}{l}\text { Placebo group } \\
(\mathbf{n}=\mathbf{3 0})\end{array}$ & p-value \\
\hline Age (years) & $37.90 \pm 7.19$ & $39.76 \pm 4.75$ & $38.66 \pm 5.22$ & $>0.05$ \\
\hline BMI $\left(w t /(h t)^{2}\right]$ & $25.24 \pm 4.05$ & $26.78 \pm 2.84$ & $25.74 \pm 3.13$ & $>0.05$ \\
\hline \multicolumn{5}{|l|}{ Presenting symptoms } \\
\hline AUB & $13(43.3 \%)$ & $11(36.7 \%)$ & $15(50.0 \%)$ & \multirow{4}{*}{$>0.05$} \\
\hline Infertility & $13(43.3 \%)$ & $14(46.7 \%)$ & $9(30.0 \%)$ & \\
\hline Pain & $3(10.0 \%)$ & $3(10.0 \%)$ & $3(10.0 \%)$ & \\
\hline Abdominal mass & $1(3.3 \%)$ & $2(6.7 \%)$ & $3(10.0 \%)$ & \\
\hline \multicolumn{5}{|l|}{ Parity } \\
\hline $\mathrm{NG}$ & $14(46.7 \%)$ & $13(43.3 \%)$ & $15(50.0 \%)$ & \multirow{7}{*}{$>0.05$} \\
\hline $\mathrm{P} 1$ & $2(6.7 \%)$ & $3(10.0 \%)$ & $2(6.7 \%)$ & \\
\hline $\mathrm{P} 2$ & $4(13.3 \%)$ & $5(16.7 \%)$ & $3(10.0 \%)$ & \\
\hline P3 & $4(13.3 \%)$ & $3(10.0 \%)$ & $5(16.7 \%)$ & \\
\hline P5 & $3(10.0 \%)$ & $3(10.0 \%)$ & $3(10.0 \%)$ & \\
\hline P1CS & $2(6.7 \%)$ & $2(6.7 \%)$ & $1(3.3 \%)$ & \\
\hline P2CS & $1(3.3 \%)$ & $1(3.3 \%)$ & $1(3.3 \%)$ & \\
\hline
\end{tabular}

There was no statistically significant difference between groups according to myoma site, myoma size and myoma number (Table 2). 
Table (2): Comparison between group A \& group B and group C according myoma characteristics

\begin{tabular}{|c|c|c|c|c|}
\hline $\begin{array}{ll}\text { Parameters } & \text { Groups } \\
\end{array}$ & $\begin{array}{c}\text { TXA+ Ethamsylate } \\
(\mathbf{n}=\mathbf{3 0})\end{array}$ & $\begin{array}{c}\text { Oxytocin } \\
(\mathbf{n}=\mathbf{3 0})\end{array}$ & $\begin{array}{l}\text { Placebo group } \\
\quad(n=30)\end{array}$ & p-value \\
\hline \multicolumn{5}{|l|}{ Myoma site } \\
\hline Intramural & $15(50.0 \%)$ & $18(60.0 \%)$ & $16(53.3 \%)$ & \multirow{2}{*}{$>0.05$} \\
\hline Subserous & $15(50.0 \%)$ & $12(40.0 \%)$ & $14(46.7 \%)$ & \\
\hline \multicolumn{5}{|l|}{ Myoma size } \\
\hline Mean \pm SD & $20.32 \pm 6.04$ & $18.94 \pm 4.72$ & $19.63 \pm 5.38$ & \multirow{2}{*}{$>0.05$} \\
\hline Range & 4-28 & $3-30$ & $5-27$ & \\
\hline \multicolumn{5}{|l|}{ Myoma number } \\
\hline 1.00 & $5(16.7 \%)$ & $5(16.7 \%)$ & $7(23.3 \%)$ & \multirow{5}{*}{$>0.05$} \\
\hline 2.00 & $7(23.3 \%)$ & $9(30.0 \%)$ & $8(26.7 \%)$ & \\
\hline 3.00 & $12(40.0 \%)$ & $10(33.3 \%)$ & $6(20.0 \%)$ & \\
\hline 4.00 & $3(10.0 \%)$ & $4(13.3 \%)$ & $5(16.7 \%)$ & \\
\hline 5.00 & $3(10.0 \%)$ & $2(6.7 \%)$ & $4(13.3 \%)$ & \\
\hline
\end{tabular}

The reduction in hemoglobin $(0.87 \pm 0.05$ vs $1.71 \pm 0.37 \mathrm{~g} / \mathrm{dl}) \quad$ was significantly lower in the Tranexamic acid and ethamsylate group than oxytocin group respectively and $(1.71 \pm 0.37 \mathrm{~g} / \mathrm{dl} \mathrm{vs}$
$2.18 \pm 0.37 \mathrm{~g} / \mathrm{dl}$ ) between oxytocin group and placebo group respectively. There was a highly statistically significant difference between groups according to mean difference of $\mathrm{Hb}$ (Table 3).

Table (3): Comparison between group $\mathrm{A} \&$ group $\mathrm{B}$ and group $\mathrm{C}$ according to $\mathrm{Hb}$

\begin{tabular}{|c|c|c|c|c|c|c|}
\hline Hb Groups & $\begin{array}{c}\text { TXA+ Ethamsylate } \\
(\mathbf{n}=30)\end{array}$ & $\begin{array}{c}\text { Oxytocin } \\
(n=30)\end{array}$ & $\begin{array}{c}\text { Placebo group } \\
\quad(n=30)\end{array}$ & $\begin{array}{c}\text { p- } \\
\text { value }\end{array}$ & \multicolumn{2}{|c|}{$\begin{array}{l}\text { Post hoc } \\
\text { (LSD) }\end{array}$} \\
\hline \multicolumn{7}{|l|}{ Preoperative } \\
\hline Mean \pm SD & $10.89 \pm 0.98$ & $10.85 \pm 0.41$ & $10.92 \pm 0.41$ & $>0.05$ & & \\
\hline Range & $10-12.4$ & $10-10.2$ & $10-10.1$ & & & \\
\hline \multicolumn{7}{|l|}{ Postoperative } \\
\hline \multirow{2}{*}{ Mean \pm SD } & \multirow{2}{*}{$10.02 \pm 0.93$} & \multirow{2}{*}{$9.14 \pm 0.79$} & \multirow{2}{*}{$8.74 \pm 0.77$} & \multirow{2}{*}{$<0.001$} & P1 & $<0.001$ \\
\hline & & & & & P2 & $<0.001$ \\
\hline Range & $8.9-11.3$ & $7.1-10$ & $6.3-9.5$ & & P3 & $>0.05$ \\
\hline \multirow{3}{*}{ Reduction } & \multirow{3}{*}{$0.87 \pm 0.05$} & \multirow{3}{*}{$1.71 \pm 0.37$} & \multirow{3}{*}{$2.18 \pm 0.37$} & \multirow{3}{*}{$<0.001$} & P1 & $<0.001$ \\
\hline & & & & & $\mathbf{P 2}$ & $<0.001$ \\
\hline & & & & & $\mathbf{P 3}$ & $<0.001$ \\
\hline
\end{tabular}

The reduction in hematocrit $(2.61 \pm 0.15 \% \quad$ vs $\quad 6.18 \pm 1.79 \%) \quad$ was significantly lower in the Tranexamic acid and ethamsylate group than oxytocin group respectively. There was a highly statistically significant difference between groups according to mean difference of HCT (Table 4). 
Table (4): Comparison between group $\mathrm{A} \&$ group $\mathrm{B}$ and group $\mathrm{C}$ according to hematocrit HCT

\begin{tabular}{|c|c|c|c|c|c|c|}
\hline HCT Groups & $\begin{array}{c}\text { TXA+ } \\
\text { Ethamsylate } \\
(\mathbf{n}=\mathbf{3 0})\end{array}$ & $\begin{array}{c}\text { Oxytocin } \\
(\mathbf{n}=\mathbf{3 0})\end{array}$ & $\begin{array}{l}\text { Placebo group } \\
\qquad(\mathbf{n}=\mathbf{3 0})\end{array}$ & p-value & \multicolumn{2}{|c|}{$\begin{array}{l}\text { Post hoc } \\
\text { (LSD) }\end{array}$} \\
\hline \multicolumn{5}{|l|}{ Preoperative } & & \\
\hline Mean \pm SD & $32.66 \pm 2.95$ & $32.18 \pm 1.23$ & $31.54 \pm 1.21$ & \multirow{2}{*}{$>0.05$} & & \\
\hline Range & $29.4-37.2$ & $28.6-36.6$ & $29.6-36.9$ & & & \\
\hline Postoperative & & & & & P1 & $<0.001$ \\
\hline Mean \pm SD & $30.06 \pm 2.80$ & $26.00 \pm 3.02$ & $24.22 \pm 2.96$ & \multirow{2}{*}{$<0.001$} & $\mathbf{P 2}$ & $<0.001$ \\
\hline Range & $26.7-33.9$ & $20-28$ & $18-26$ & & P3 & $>0.05$ \\
\hline \multirow{3}{*}{ Reduction } & \multirow{3}{*}{$2.61 \pm 0.15$} & \multirow{3}{*}{$6.18 \pm 1.79$} & \multirow{3}{*}{$7.32 \pm 1.75$} & \multirow{3}{*}{$<0.001$} & P1 & $<0.001$ \\
\hline & & & & & $\mathbf{P 2}$ & $<0.001$ \\
\hline & & & & & $\mathbf{P 3}$ & $<0.01$ \\
\hline
\end{tabular}

There was a highly statistically significant difference between groups according to mean difference of towels' weight. The difference in towels' weight
$(265.92 \pm 22.04$ vs $438.19 \pm 50.00)$ was significantly lower in the Tranexamic acid and ethamsylate group than oxytocin group respectively (Table 5).

Table (5): Comparison between group $A \&$ group $B$ and group $C$ according to towels' weight

\begin{tabular}{|c|c|c|c|c|c|c|}
\hline $\begin{array}{l}\text { Groups } \\
\text { Towels } \\
\text { weight }\end{array}$ & $\begin{array}{c}\text { TXA+ } \\
\text { Ethamsylate } \\
(\mathbf{n}=\mathbf{3 0})\end{array}$ & $\begin{array}{c}\text { Oxytocin } \\
(\mathbf{n}=\mathbf{3 0})\end{array}$ & $\begin{array}{l}\text { Placebo group } \\
\quad(\mathbf{n}=\mathbf{3 0})\end{array}$ & $\begin{array}{c}\text { p- } \\
\text { value }\end{array}$ & \multicolumn{2}{|c|}{$\begin{array}{l}\text { Post hoc } \\
\text { (LSD) }\end{array}$} \\
\hline \multicolumn{7}{|l|}{ Preoperative } \\
\hline Mean \pm SD & $150.0 \pm 0.0$ & $150.0 \pm 0.0$ & $150.0 \pm 0.0$ & & & \\
\hline Range & $150-150$ & $150-150$ & $150-150$ & $>0.05$ & & \\
\hline Postoperative & & & & & P1 & $<0.001$ \\
\hline Mean \pm SD & $415.92 \pm 32.41$ & $588.19 \pm 73.53$ & $638.51 \pm 72.06$ & $<0.001$ & $\mathbf{P 2}$ & $<0.001$ \\
\hline Range & $374-465$ & $522-690$ & $531-690$ & & $\mathbf{P 3}$ & $<0.01$ \\
\hline \multirow{3}{*}{$\begin{array}{l}\text { Mean } \\
\text { difference }\end{array}$} & \multirow{3}{*}{$265.92 \pm 22.04$} & \multirow{3}{*}{$438.19 \pm 50.00$} & \multirow{3}{*}{$488.51 \pm 49.00$} & \multirow{3}{*}{$<0.001$} & P1 & $<0.001$ \\
\hline & & & & & $\mathbf{P 2}$ & $<0.001$ \\
\hline & & & & & $\mathbf{P 3}$ & $<0.001$ \\
\hline
\end{tabular}

There was a highly statistically significant difference between groups according to mean difference of suction bottle weight. The difference in suction bottle weight $(247.32 \pm 41.39$ vs
$345.39 \pm 35.71$ a) was significantly lower in the Tranexamic acid and ethamsylate group than oxytocin group respectively (Table 6). 
Table (6): Comparison between group $A \&$ group $B$ and group $C$ according to suction bottle weight

\begin{tabular}{|c|c|c|c|c|c|c|}
\hline $\begin{array}{l}\text { Groups } \\
\text { Suction } \\
\text { bottle weight }\end{array}$ & $\begin{array}{c}\text { TXA+ } \\
\text { Ethamsylate } \\
(\mathbf{n}=\mathbf{3 0})\end{array}$ & $\begin{array}{c}\text { Oxytocin } \\
(\mathbf{n}=30)\end{array}$ & $\begin{array}{l}\text { Placebo group } \\
\qquad(\mathbf{n}=\mathbf{3 0})\end{array}$ & $\begin{array}{c}p- \\
\text { value }\end{array}$ & \multicolumn{2}{|c|}{$\begin{array}{l}\text { Post hoc } \\
\text { (LSD) }\end{array}$} \\
\hline \multicolumn{7}{|l|}{ Preoperative } \\
\hline Mean \pm SD & $250.0 \pm 0.0$ & $250.0 \pm 0.0$ & $250.0 \pm 0.0$ & $>0.05$ & & \\
\hline Range & $250-250$ & $250-250$ & $250-250$ & & & \\
\hline Postoperative & & & & & P1 & $<0.001$ \\
\hline Mean \pm SD & $497.32 \pm 60.87$ & $595.39 \pm 52.52$ & $667.69 \pm 51.47$ & $<0.001$ & $\mathbf{P 2}$ & $<0.001$ \\
\hline Range & $398-564$ & $550-700$ & $580-765$ & & P3 & $<0.001$ \\
\hline \multirow{3}{*}{$\begin{array}{l}\text { Mean } \\
\text { difference }\end{array}$} & \multirow{3}{*}{$247.32 \pm 41.39$} & \multirow{3}{*}{$345.39 \pm 35.71$} & \multirow{3}{*}{$417.69 \pm 35.00$} & \multirow{3}{*}{$<0.001$} & P1 & $<0.001$ \\
\hline & & & & & $\mathbf{P 2}$ & $<0.001$ \\
\hline & & & & & P3 & $<0.001$ \\
\hline
\end{tabular}

There was a highly statistically significant difference between groups according to blood loss. It was found that the amount of intraoperative blood loss was significantly lower in those women randomized to receive $1 \mathrm{~g}$ tranexamic acid and 1 amp ethamsylate versus 30 iu oxytocin infusion. The amount of blood loss (408-566 vs 680-890) was significantly lower in the Tranexamic acid and ethamsylate group than oxytocin group respectively (Table 7).

Table (7): Comparison between group A \& group B and group $C$ according to blood loss

\begin{tabular}{|c|c|c|c|c|c|c|}
\hline Blood Loss & $\begin{array}{c}\text { TXA+ } \\
\text { Ethamsylate } \\
(n=30)\end{array}$ & $\begin{array}{c}\text { Oxytocin } \\
(\mathbf{n}=\mathbf{3 0})\end{array}$ & $\begin{array}{l}\text { Placebo group } \\
\qquad(\mathbf{n}=\mathbf{3 0})\end{array}$ & p-value & & $\begin{array}{l}\text { st hoc } \\
\text { SD) }\end{array}$ \\
\hline Mean \pm SD & $509.24 \pm 57.28$ & $720.13 \pm 112.62$ & $838.30 \pm 90.90$ & \multirow{2}{*}{$<0.001$} & P1 & $<0.001$ \\
\hline Range & $408-566$ & $680-890$ & $740-990$ & & P2 & $<0.001$ \\
\hline
\end{tabular}

There was a statistically significant difference between groups according blood transfusion and parenteral iron transfusion. The need for blood transfusion (0 vs 11) was significantly lower in the Tranexamic acid and ethamsylate group than oxytocin group respectively (Table 8).

Table (8): Comparison between group A \& group B and group $\mathrm{C}$ according to blood transfusion and parenteral iron transfusion

\begin{tabular}{|c|c|c|c|c|}
\hline Parameters & $\begin{array}{c}\text { TXA+ } \\
\text { Ethamsylate } \\
(\mathbf{n = 3 0})\end{array}$ & $\begin{array}{c}\text { Oxytocin } \\
(\mathbf{n = 3 0})\end{array}$ & $\begin{array}{c}\text { Placebo group } \\
(\mathbf{n = 3 0})\end{array}$ & $\begin{array}{c}\text { p- } \\
\text { value }\end{array}$ \\
\hline $\begin{array}{c}\text { Intra or Post-operative } \\
\text { blood transfusion }\end{array}$ & & & & \\
\hline 1 unit & $0(0.0 \%)$ & $6(20.0 \%)$ & $8(26.7 \%)$ & $\mathbf{0 . 0 1 2}$ \\
\hline No & $30(100.0 \%)$ & $24(80.0 \%)$ & $22(73.3 \%)$ & \\
\hline $\begin{array}{c}\text { Postoperative parenteral iron } \\
\text { transfusion }\end{array}$ & & & & \\
\hline No & $30(100.0 \%)$ & $25(83.3 \%)$ & $24(80.0 \%)$ & $\mathbf{0 . 0 4 0}$ \\
\hline Yes & $0(0.0 \%)$ & $5(16.7 \%)$ & $6(20.0 \%)$ & \\
\hline
\end{tabular}


There was no statistically significant difference between groups according to hospital stay. Tranexamic acid and ethamsylate lead to statistically insignificant in the hospital length of stay when compared with oxytocin group i.e. 2.2 day in the Tranexamic acid and ethamsylate group vs 2.4 Day in the oxytocin group (Table 9).

Table (9): Comparison between group A \& group B and group C according to hospital stay

\begin{tabular}{|l|c|c|c|c|}
\hline Hospital stay & $\begin{array}{c}\text { Groups } \\
\text { TXA+ Ethamsylate } \\
(\mathbf{n = 3 0 )}\end{array}$ & $\begin{array}{c}\text { Oxytocin } \\
(\mathbf{n = 3 0})\end{array}$ & $\begin{array}{c}\text { Placebo group } \\
(\mathbf{n}=\mathbf{3 0})\end{array}$ & p-value \\
\cline { 1 - 4 } Mean \pm SD & $2.22 \pm 1.24$ & $2.42 \pm 1.38$ & $2.66 \pm 1.65$ & \multirow{2}{*}{$>0.05$} \\
\cline { 1 - 3 } Range & $1-6$ & $1-7$ & $1-8$ & \\
\hline
\end{tabular}

There was no statistically significant difference between groups according to

Postoperative wound infection and Postoperative fever (Table 10).

Table (10): Comparison between group $A$ \& group $B$ and group $C$ according to wound infection and fever

\begin{tabular}{|c|c|c|c|c|}
\hline Parameters $\quad$ Groups & $\begin{array}{c}\text { TXA+Ethamsylate } \\
(n=30)\end{array}$ & $\begin{array}{c}\text { Oxytocin } \\
(\mathbf{n}=30)\end{array}$ & $\begin{array}{c}\text { Placebo group } \\
(\mathbf{n}=\mathbf{3 0})\end{array}$ & p-value \\
\hline \multicolumn{5}{|l|}{$\begin{array}{l}\text { Postoperative wound } \\
\text { infection }\end{array}$} \\
\hline No & $27(90.0 \%)$ & $26(86.7 \%)$ & $24(80.0 \%)$ & \multirow{2}{*}{$>0.05$} \\
\hline Yes & $3(10.0 \%)$ & $4(13.3 \%)$ & $6(20.0 \%)$ & \\
\hline \multicolumn{5}{|l|}{ Postoperative fever } \\
\hline No & $26(86.7 \%)$ & $24(80.0 \%)$ & $22(73.3 \%)$ & \multirow{2}{*}{$>0.05$} \\
\hline Yes & $4(13.3 \%)$ & $6(20.0 \%)$ & $8(26.7 \%)$ & \\
\hline
\end{tabular}

There was no statistically significant difference between groups according to operative time (Table 11).

Table (11): Comparison between group $A$ \& group $B$ and group $C$ according to operative time

\begin{tabular}{|l|c|c|c|c|}
\hline Operative time & $\begin{array}{c}\text { Groups } \\
\text { TXA+Ethamsylate } \\
(\mathbf{n}=\mathbf{3 0})\end{array}$ & $\begin{array}{c}\text { Oxytocin } \\
(\mathbf{n = 3 0})\end{array}$ & $\begin{array}{c}\text { Placebo group } \\
(\mathbf{n}=\mathbf{3 0})\end{array}$ & p-value \\
\cline { 1 - 4 } Mean \pm SD & $56.56 \pm 7.53$ & $60.60 \pm 10.87$ & $62.62 \pm 8.83$ & \multirow{2}{*}{0.038} \\
\hline Range & $45-65$ & $45-72$ & $46-75$ & \\
\hline
\end{tabular}

There were significant positive correlations between blood loss with myoma size, myoma number and postoperative suction bottle weight, while postoperative $\mathrm{Hb}$ and postoperative $\mathrm{HCT}$ showed a significant negative correlation, in TXA+ ethamsylate grop. There were significant positive correlations between blood loss with myoma size, myoma number, postoperative towels weight and postoperative suction bottle weight, while postoperative $\mathrm{Hb}$ and postoperative $\mathrm{HCT}$ showed a significant negative correlation, in oxytocin grop. There were significant positive correlations between blood loss with myoma size and postoperative suction bottle weight, while postoperative $\mathrm{Hb}$ and postoperative HCT showed a significant negative correlation, in placebo group (Table 12). 
Table (12): Correlation between blood loss and other parameters, using Pearson correlation coefficient

\begin{tabular}{|l|c|c|c|c|c|c|}
\hline \multirow{2}{*}{ Groups } & $\begin{array}{c}\text { TXA+ Ethamsylate } \\
\text { Bn=30) }\end{array}$ & \multicolumn{2}{c|}{$\begin{array}{c}\text { Oxytocin } \\
(\mathbf{n = 3 0})\end{array}$} & \multicolumn{2}{c|}{$\begin{array}{c}\text { Placebo group } \\
(\mathbf{n = 3 0})\end{array}$} \\
\cline { 2 - 7 } & $\mathbf{r}$ & $\mathbf{p}-$-value & $\mathbf{r}$ & $\mathbf{p}$-value & $\mathbf{r}$ & $\mathbf{p}$-value \\
\hline Myoma size & -0.778 & $<0.001$ & -0.743 & $<0.001$ & -0.498 & $<0.001$ \\
\hline Myoma number & 0.410 & 0.014 & 0.344 & 0.007 & 0.231 & $>0.05$ \\
\hline Postoperative HB & 0.719 & $<0.001$ & -0.680 & $<0.001$ & -0.455 & $<0.001$ \\
\hline Postoperative HCT & 0.719 & $<0.001$ & -0.762 & $<0.001$ & -0.511 & $<0.001$ \\
\hline $\begin{array}{l}\text { Postoperative } \\
\text { towels' weight }\end{array}$ & 0.177 & $>0.05$ & 0.685 & $<0.001$ & 0.116 & $>0.05$ \\
\hline $\begin{array}{l}\text { Postoperative suction } \\
\text { bottle weight }\end{array}$ & 0.798 & $<0.001$ & 0.801 & $<0.001$ & 0.537 & $<0.001$ \\
\hline
\end{tabular}

\section{DISCUSSION}

Fibroids are the most common muscular tumors that affect women of childbearing age. They are almost always benign. It is estimated that between 20 to 50 percent of women of reproductive age have fibroids. The current treatments for uterine fibroids are many, but surgical resection is still the main treatment. Surgical removal of myomas is by abdominal myomectomy (Yang et al., 2018).

Till the time being there is only one study comparing the use of tranexamic acid versus oxytocin infusion in decreasing blood loss during abdominal myomectomy (Jafari et al., 2018). There are other studies comparing the use of tranexamic acid versus placebo during abdominal myomectomy (Topsoee et al., 2017; Fusca et al., 2018 and Shady et al., 2018). And the use of oxytocin versus placebo during abdominal myomectomy (Kongnyuy and Wiysonge., 2014 and Çetin, 2019).

In this study, there were no statistically significant differences between both groups regarding age, parity, body mass index, uterine size number of fibroids, type of fibroid and diameter of largest fibroid. It also showed no statistically significant difference between the three groups regarding the presenting symptoms of the patients. Number of fibroids, type of fibroid and diameter of largest fibroid were not independent predictors of blood loss. The amount of intraoperative blood loss was significantly lower in those women randomized to receive $1 \mathrm{~g}$ tranexamic acid and 1 amp ethamsylate versus 30 iu oxytocin infusion. This was possibly because tranexamic acid was acting to reduce blood loss through mechanism of fibrinolysis inhibition as it served as an antifibrinolytic. on the other hand, the concentration of oxytocin receptors existed in the non -pregnant uterus was much lower than in its pregnancy. So, we have to use oxytocin in a large dose to act on oxytocin receptors in the myometrium and fibroid tissue, which stimulates synthesis and release of contractile prostaglandins and so decreases blood supply to the arteries and fibroids. This result agreed with the study which demonstrated that the average blood loss during abdominal myomectomy was significantly higher in those women randomized to receive 30 iu 
oxytocin infusion versus 400 microgram rectal misoprostol.

Jafari-Shobeiri and Colleagues (2018) showed that tranexamic acid was effective in decreasing blood loss during the myomectomy. They did not use a precise way of estimation of blood loss; the used way was counting the mops used during the operation.

In this study, we used a precise way by adding the difference in weight between the dry and soaked linen towels before and after the operation, assuming the $1 \mathrm{ml}$ of blood equal $1 \mathrm{~g}$ of blood (Vitello et al., 2015).

Shady and Colleagues (2018) showed a great reduction in intraoperative and postoperative blood loss.

Only the intraoperative blood loss was measured in this study and the same was done in the study of Jafari-Shobeiri et al. (2018) despite the different ways of estimation of blood loss, while in study of Shady besides measuring the intraoperative blood loss, the postoperative blood loss was also measured as the amount of blood in the suction drain which was kept for 48 hrs. Postoperatively, and this was a limitation of this study.

The present study supported the study by Fusca et al. (2018) who found that intra -operative blood loss was significantly lower in those women randomized to receive tranexamic acid versus the placebo groups during abdominal myomectomy.

In the current study and the studies of Topsoee et al. (2017), Fusca et al. (2018) and Shady et al. (2018), tranexamic acid was administrated by different routes (intra-venous and topical) and in variable dosages however it still decreasing Intraoperative blood loss.

Kongnyuy and Wiysonge (2014) observed that intra-operative blood loss was not significantly lower in those women randomized to receive oxytocin versus the placebo group. Atashkhoei et al. (2017) and Çetin et al. (2019), when the dose of oxytocin was increased to 30 IU, the intra-operative blood loss was significantly lower in those women randomized to receive oxytocin versus the placebo group.

In the present study, blood transfusion was required for more patients in the oxytocin group than the tranexamic acid and ethasmsylate group. However, there was no statistically significant difference between both groups.

Regarding the operative time in our study, it was significantly shorter in the tranexamic acid and ethasmsylate group vs. oxytocin group as a result of the decrease in the blood loss and better surgical field, and these results agreed with the results reported by JafariShobeiri et al. (2018), where operative time was shorter in the tranexamic acid and ethamsylate group vs, the oxytocin group. Fusca et al. (2018) demonstrated that operative time was significantly shorter in the tranexamic acid and ethamsylate group compared with placebo group. Cetin et al. (2019) found that the duration of the operation was significantly shorter in the oxytocin group compared with placebo group.

In the present study, we compared the preoperative and postoperative hemoglobin, the preoperative and postoperative hematocrit, and we found 
that the reduction in hemoglobin was significantly lower in the tranexamic acid and ethamsylate group than oxytocin group, also the reduction in hematocrit was significantly lower in the tranexamic acid and ethamsylate group than oxytocin group. These results agreed with results reported by Jafari-Shobeiri et al. (2018) who found that tranexamic acid group had postoperative hemoglobin values that was significantly higher than those found in oxytocin group, and found that tranexamic acid group had postoperative hematocrit values that was higher than those found in the oxytocin group.

The present study supported the study by Fusca et al. (2018) who found that hemoglobin reduction was lower in tranexamic acid group than control group. Topsoee et al. (2017) demonstrated that the drop in hemoglobin concentration and hematocrit percentage was significantly lower in the study tranexamic acid group compared with the control group.

Kongnyuy and Wiysonge, (2014) stated that the change in hemoglobin level from the day before the operation and $48 \mathrm{~h}$ after surgery not differ significantly between the oxytocin group and the placebo group. However, in another study by Çetin et al. (2019), when the dose of oxytocin increased, the hemoglobin and hematocrit reduction was lower in the oxytocin group than the placebo group.

In our study, as regard the hospital length of stay, the differences between the tranexamic acid and ethamsylate group and oxytocin group were not statistically significant and these results agree with the results reported by Jafari-Shobeiri et al. (2018) in which length of stay in hospital in the two groups did not show a significant difference. Investigations have reported that the most common side effects after administration of $2 \mathrm{gm}$ tranexamic acid and ethamsylate are blurred vision, hypotension, diarrhea, nausea and vomiting (Goobie, 2017).

On the other hand, major side effects of oxytocin include hypotension, tachyarrethymias or hyponatremia (water intoxication) (Duffield et al., 2017). In our study, there were no important side effects in the patients who had received tranexamic acid and ethamsylate or oxytocin. The differences between the tranexamic acid and ethamsylate group and oxytocin group were not statistically significant. This agrees with the study by Jafari-Shobeiri et al. (2018). This was possibly because we administered a single dose of tranexamic acid and ethamsylate or relatively low dose of oxytocin, and after surgery the patients were either still anesthetized or under the effect of an analgesic.

Tranexamic acid and ethamsylate has the advantage of the cost compared to GnRH analogs the most popular method for reducing hemorrhage in myomectomy. Although this is not their primary use, these $\mathrm{GnRH}$ analogs were the first treatment to be employed for myomas. However, the growth of myomas after the treatment has been noted, as well as developing the osteoporosis in long-term use; thus, GnRH analog use has been restricted only to decrease the myoma volume preoperatively and to reduce intraoperative blood loss. Another advantage over GnRH analogues is that the effect of $\mathrm{GnRH}$ analogues attained only after a lost time while tranexamic acid and ethamsylate can be administered 
just before the operation (Sancho et al., 2016).

Tranexamic acid and ethamsylate have many advantages when compared to vasopressin; cost concerns are partially valid for vasopressin treatment as well as safety concerns. Some side effects have been reported to arise from the use of intraoperative vasopressin: temporary increase in blood pressure during local vasopressin injection, bleeding at injection site, and intravascular infiltration by mistake Vezhaventhan et al., (2018). In addition, Obaji et al. (2016) reported pulmonary edema after the use of local vasopressin, and Chilkoti et al. (2016) reported myocardial infarction.

\section{CONCLUSION}

Tranexamic acid and ethamsylate were more effective in reducing the transfusion requirement than oxytocin with more stable hematological and hemodynamic profile.

\section{REFERENCES}

1. Atashkhoei, S., Fakhari, S., Pourfathi, H., Bilehjani, E., Garabaghi, P. M. and Asiaei, A (2017): Effect of oxytocin infusion on reducing the blood loss during abdominal myomectomy: a double blind randomised controlled trial. BJOG: International Journal of Obstetrics \& Gynaecology, 124(2): 292-8.

2. Bano, S. N., Jafri, M. A., Kazmi, Q. A., Begum, W. and Ansari, Z. A. (2017): Uterine Myoma Symptoms \& Quality of Life. Women's Health, 4(1): 555630-4.

3. Bradley, L. D. and Gueye, N. A. (2016): The medical management of abnormal uterine bleeding in reproductive-aged women. American Journal of Obstetrics and Gynecology, 214(1): 31-44.

4. Çetin, B. A., Mathyk, B. A., Köroğlu, N., Soydar, A., Demirayak, G. and Çift, T. (2019): Oxytocin infusion reduces bleeding during abdominal myomectomies: a randomized controlled trial. Archives of Gynecology and Obstetrics, 299(1): 151-7.

5. Chilkoti, G., Mohta, M., Nath, S., Saxena, A. K. and Khurana, P. (2016): Anaesthetic concerns with intramyometrial vasopressin during myomectomy. Ain-Shams Journal of Anaesthesiology, 9(3): 452-6.

6. Cohen, S. L., Senapati, S., Gargiulo, A. R., Srouji, S. S., Tu, F., Solnik, J and Einarsson, J. I. (2016): Dilute Versus Concentrated Vasopressin Administration During Laparoscopic Myomectomy: A Randomized Controlled Trial. Obstetrical \& Gynecological Survey, 71(10): 588-9.

7. Duffield, A., McKenzie, C., Carvalho, B., Ramachandran, B., Yin, V., El-Sayed, Y. Y. and Butwick, A. J. (2017): Effect of a HighRate Versus a Low-Rate Oxytocin Infusion for Maintaining Uterine Contractility During Elective Cesarean Delivery: A Prospective Randomized Clinical Trial. Anesthesia and Analgesia, 124(3): 857-62.

8. Farag, S., Padilla, P. F., Smith, K. A., Sprague, M. L. and Zimberg, S. E. (2018): Management, Prevention, and Sequelae of Adhesions in Women Undergoing Laparoscopic Gynecologic Surgery: a Systematic Review. Journal of Minimally Invasive Gynecology, 25(7): 1194-216.

9. Fatah, A. T. A., El-Mohandes, M. I. and ElMadany, Y. A. (2018): Tranexamic Acid and Ethamsylate for Reducing Blood Loss in Patient Undergoing LSCS at High Risk for Postpartum Hemorrhage. The Egyptian Journal of Hospital Medicine, 73(4): 6452-6.

10. Fusca, L., Perelman, I., Fergusson, D., Boutet, M. and Chen, I. (2018): The effectiveness of tranexamic acid at reducing blood loss and transfusion requirement for women undergoing myomectomy: a systematic review and meta-analysis. Journal of Obstetrics and Gynaecology Canada, 41(8):1185-92.

11. Goobie, S. M. (2017): Tranexamic acid: still far to go. BJA: British Journal of Anaesthesia, 118(3): 293-5.

12. Jafari-Shobeiri, M., Nourozvand, M., Mostafa-Gharabaghi, P., Sayyah-Melli, M., 
Ouladsahebmadarek, E., Atashkhoyi, S. and Salimian, S. (2018): The Comparative study of Intravenous Tranexamic Acid with Intravenous Oxytocin in the Control of Bleeding during Hysteroscopic Myomectomy in Women with Abnormal Uterine Bleeding. Journal of Biochemical Technology, 87-92 (2): 974-8.

13. Kongnyuy, E. J. and Wiysonge, C. S. (2014): Interventions to reduce haemorrhage during myomectomy for fibroids. Cochrane Database of Systematic Reviews, 15(8): 5355-63.

14. Kuzume, A., Sugimi, S., Suga, S., Yamashita, H. and Yasuhi, I. (2017): The Routine Use of Prophylactic Oxytocin in the Third Stage of Labor to Reduce Maternal Blood Loss. Journal of pregnancy, 2017(2017):3274-9.

15. Lecker, I., Wang, D. S., Whissell, P. D., Avramescu, S., Mazer, C. D. and Orser, B. A. (2016): Tranexamic acid-associated seizures: Causes and treatment. Annals of Neurology, 79(1): 18-26.

16. Obaji, S., Alikhan, R., Rayment, R., Carter, P., Macartney, N. and Collins, P. (2016): Unclassified bleeding disorders: outcome of haemostatic challenges following tranexamic acid and/or desmopressin. Haemophilia, 22(2): 285-91.

17. Petermans, S., Ameye, L., Timmerman, D. and Verguts, J. (2016): Ultrasonography in the prediction of complications during and after uterine myomectomy. Gynecological Surgery, 13(4): 507-14.

18. Ramos-Sánchez, T. A., Ramos-Morales, T., Morales-Avalos, R., Blázquez-Saldaña, J., Peña-Martínez, V. M. and Vílchez-Cavazos, F. (2018): Use of ethamsylate to reduce postoperative bleeding and transfusion index in total hip arthroplasty.A randomized clinical trial. Cirugía y Cirujanos, 86(3): 270-6.

19. Reis, F. M., Bloise, E. and Ortiga-Carvalho, T. M. (2016): Hormones and pathogenesis of uterine fibroids. Best Practice \& Research Clinical Obstetrics \& Gynaecology, 34, 13-24.

20.Saha, M. M., Khushboo, S. C. B., Alam, H., Kamilya, G. S., Mukhopadhyay, M. and Mondal, S. (2016): Assessment of blood loss in abdominal myomectomy by intramyometrial vasopressin administration versus conventional tourniquet application. Journal of clinical and diagnostic research: JCDR, 10(5):10-6.

21.Sancho, J. M., de la Cruz Delgado, V. S., Valero, M. J. N., Soteras, M. G., Amate, V. P. and Carrascosa, A. A. (2016): Hysteroscopic myomectomy outcomes after 3month treatment with either Ulipristal Acetate or GnRH analogues: a retrospective comparative study. European Journal of Obstetrics \& Gynecology and Reproductive Biology, 198, 127-30.

22. Shady, N. W., Sallam, H. F. and Fahmy, H. (2018): Reducing blood loss during open myomectomy with intravenous versus topical tranexamic acid: A double-blinded randomized placebo-controlled trial. Middle East Fertility Society Journal, 23(3): 225-31.

23. Topsoee, M. F., Settnes, A., Ottesen, B. and Bergholt, T. (2017): A systematic review and metaanalysis of the effect of prophylactic tranexamic acid treatment in major benign uterine surgery. International Journal of Gynecology \& Obstetrics, 136(2): 120-7.

24. Vallera, C., Choi, L. O., Cha, C. M. and Hong, R. W. (2017): Uterotonic medications: oxytocin, methylergonovine, carboprost, misoprostol. Anesthesiology Clinics, 35(2): 207-219.

25. Vezhaventhan, G., Soundarya, G., Saravanan, K. and Govindarajan, P. (2018): Is tranexamic acid effective in reducing turp related blood loss? A prospective study. International Journal of Current Research in Life Sciences, 7(06): 2226-8.

26. Vitello, D. J., Ripper, R. M., Fettiplace, M. R., Weinberg, G. L. and Vitello, J. M. (2015): Blood density is nearly equal to water density: a validation study of the gravimetric method of measuring intraoperative blood loss. Journal of Veterinary Medicine, 2015: 1572-5.

27. Yang, W., Luo, N., Ma, L., Dai, $H$ and Cheng, Z. (2018): The changes of surgical treatment for symptomatic uterine myomas in the past 15 Years. Gynecology and Minimally Invasive Therapy, 7(1): 10-4. 


\section{مقارنة بين تأثير حمض الترانيكساميك مع الإيثاميسيلات وبين

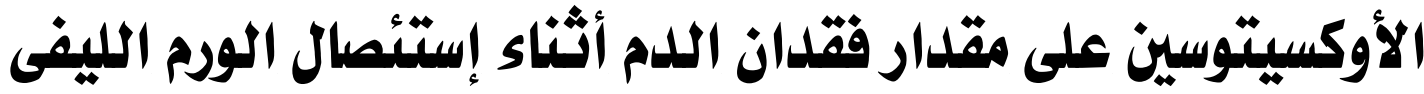

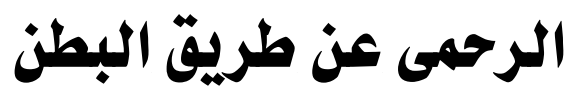

عمار مجدى على، كامل نور الدين عبد الجليل، السيد أحمد الاسوقى قسم النساء والتوليد، كلية الطب، جامعة الأزهر

E-mail: amar_maged2000@yahoo.com

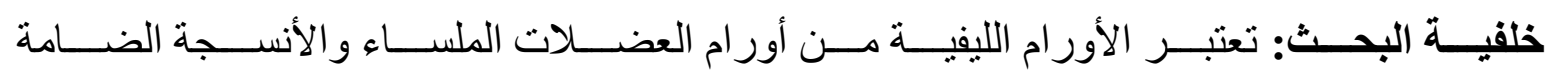

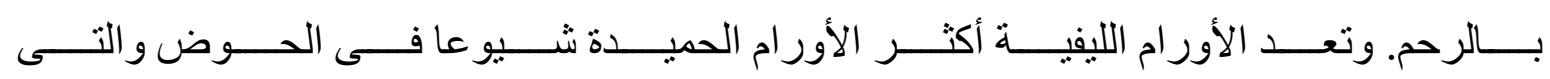

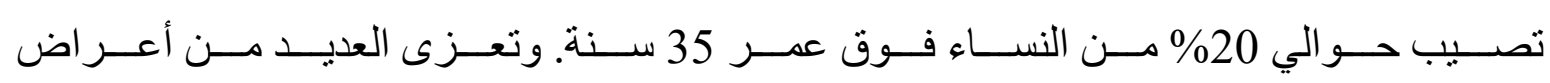

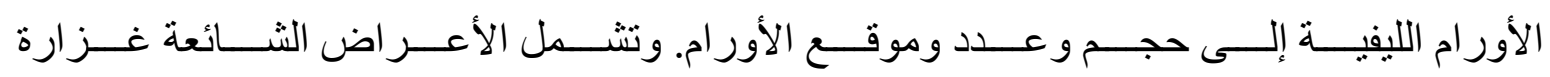
الطمث، العق، كتلة فى البطن و آثار الضغط.

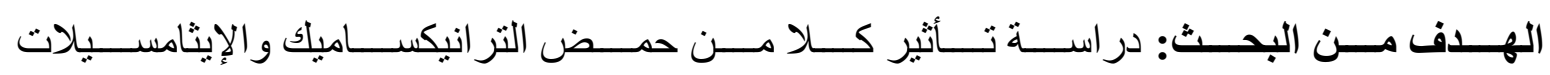

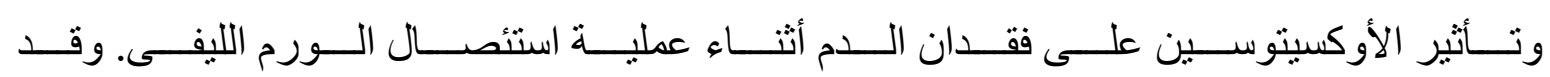

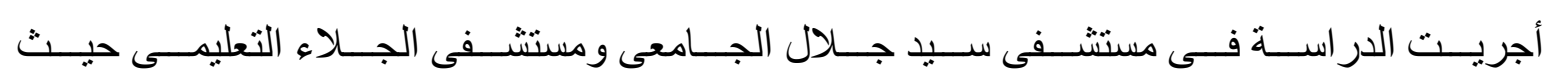
تم جمع 90 مريضة مستوفيات لمعايير الدراسة.

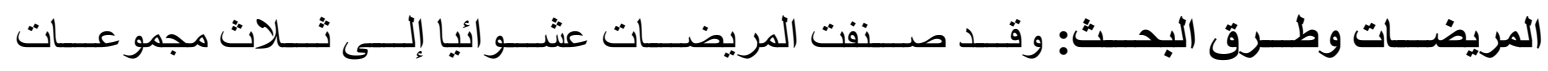
منساوية:

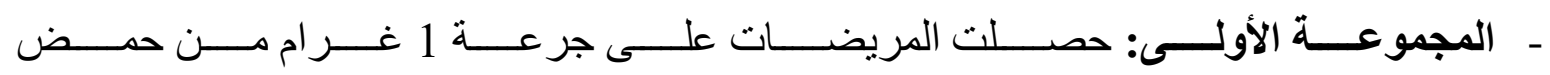

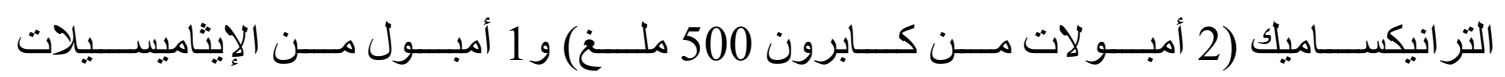
(دايسينون) وريديا قبل شق الجلد مباشرةً.

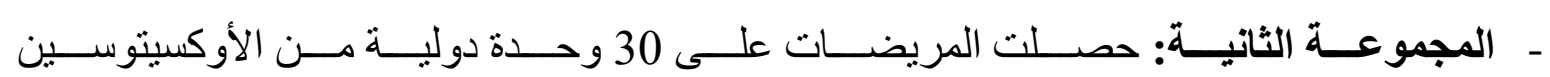
في 500 مل من محلول الملح الطبيعى خلال عملية استئصسال الورم العضلي.

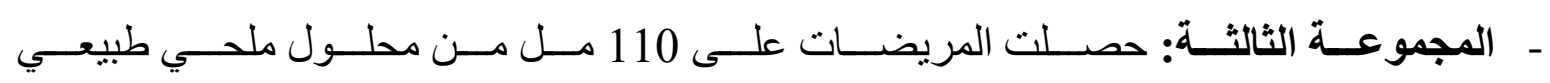
وريديا قبل شق الجلد مباشرةً. 
تتــائج البحـــث: أظهــرت مجمو عــة التر انيكســاميك و الإيثامســيلات فقــــان كميــة أقــلـ مـــن

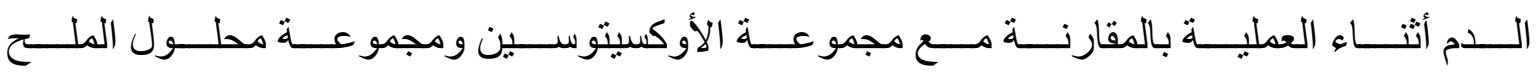
وكانت فروق ذات دلالة إحصائية.

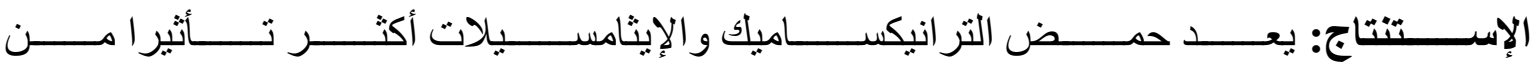

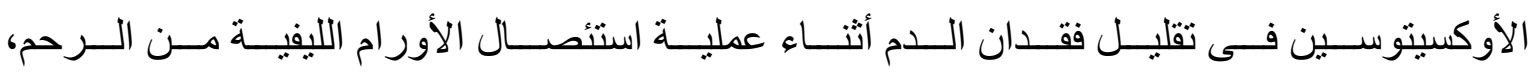
ويقلل أيضا الحاجة إلى نقل الدم أثناء وبعد العملية.

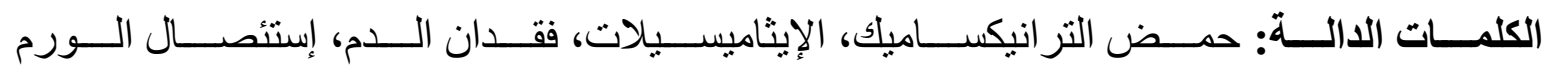
الليفى الرحمى عن طريق البطن. 